\title{
Rose Rosette Disease: Recent Advances on Molecular Diagnostic Tools
}

\author{
Binoy Babu, Gary Knox, and Mathews L. Paret ${ }^{1}$ \\ North Florida Research and Education Center, Institute of Food and Agricultural Sciences, \\ University of Florida, Quincy, FL 32351 \\ Francisco M. Ochoa-Corona ${ }^{1}$ \\ Department of Entomology and Plant Pathology, National Institute for Microbial Forensics \& \\ Food and Agricultural Biosecurity, Oklahoma State University, Stillwater, OK 74078
}

\begin{abstract}
Additional index words. diagnostics, end-point RT-PCR, TaqMan RT-qPCR, Rose rosette emaravirus, artificial positive control
Abstract. Rose rosette emaravirus (RRV, genus Emaravirus), the causal agent of rose rosette disease, is the topmost pathogen of concern for the rose industry in the United States. The only strategy available for disease management is early identification and eradication of the infected plants. Highly reliable, specific, and sensitive detection assays are thus required to test and confirm the presence of $R R V$ in suspected plant samples. RRV is only a recently characterized virus and hence limits the diagnostic tools available for its early detection. With a U.S. Department of Agriculture (USDA) Specialty Crop Research Initiative (SCRI) project sponsorship, several diagnostic tools including end-point reverse transcriptionpolymerase chain reaction (RT-PCR) and RT-qPCR assays targeting single and multiple genes targets were developed for routine diagnostics. This review introduces an overall view of the different diagnostic tools developed, which are reliable, highly sensitive, and can be easily implemented for detection and identification in laboratories providing diagnostic services and confirmation of RRV-infected samples.
\end{abstract}

\section{ROSE ROSETTE DISEASE}

Roses are one of the most important ornamental flowering shrubs grown worldwide. In the United States, the total sales of shrub rose's value was 204 million U.S. dollars in 2014 (U.S. Department of Agriculture, 2015). Among the diseases of roses, rose rosette disease has become the most devastating, causing economic losses to nurseries, landscapes, and gardeners (Stanley, 2013). The disease affects many rose species and cultivars, and has become widespread in the north-central, south-central, and southeast regions. Also, the disease has been identified on cultivated roses in the midwest, portions of the northeast, and a few western states in the United States.

Rose rosette disease is associated with RRV (genus Emaravirus), a single-stranded negative-sense RNA virus (Laney et al., 2011). The virus is transmitted by the eriophyid mite species Phyllocoptes fructiphilus (Amrine et al., 1988; Laney et al., 2011) and by grafting (Amrine et al., 1988). The mites do not fly but passively move long distances via air currents, spreading to nearby roses and infecting rose plantings with RRV (Epstein

Received for publication 2 Oct. 2017. Accepted for publication 23 Dec. 2017.

This paper is part of the workshop entitled, The Challenges of Rose Rosette Disease (RRD): An Update of the Combating RRD SCRI Project, presented on 9 Aug. 2016, during the ASHS Annual conference, Atlanta, GA.

This work was partially funded by the USDA's National Institute of Food and Agriculture (NIFA) Specialty Crop Research Initiative project "Combating Rose Rosette Disease: Short Term and Long Term Approaches."

${ }^{1}$ Corresponding authors. E-mail: paret@ufl.edu or ochoaco@okstate.edu. and Hill, 1999; Windham et al., 2014a). Rose rosette emaravirus has a multipartite genome enclosed by a double membrane-bound body of 120-150 nm in diameter (Gergerich and Kim, 1983; Gergerich et al., 1983). The RRV virion is reported to contain seven genomic RNA segments, some of which encode known functions. For example, RNA1, RNA2, RNA3, and RNA4 encode an RNAdependent RNA polymerase (RdRp), a glycoprotein, a nucleocapsid, and a movement protein, respectively, whereas RNA5, RNA6, and RNA7 have unknown function (Babu et al., 2016a; Di Bello et al., 2015; Laney et al., 2011).

\section{SYMPTOMS}

The symptoms of rose rosette disease are highly variable and depend on the rose cultivar, growth stage, and environmental conditions (Windham et al., 2014a, 2014b). Some of the symptoms include excessive thorniness, witches' broom, red pigmentation which does not disappear as the plant matures, and excessive lateral shoot growth. The disease ultimately leads to the death of the plant in 1-2 years (Amrine, 2002). Diagnosis of rose rosette disease in early stages could be misleading because of its resemblance to symptoms caused by herbicide damage or other plant viruses. The only effective strategy for disease management is early identification and eradication of the infected plants, thereby limiting the spread of RRV. Early identification requires a highly reliable, specific, and sensitive detection assay for either detection or confirmation of the rose rosette disease.

Rose rosette emaravirus is a recently characterized virus and little is known about its diversity and biology. Currently, neither enzyme-linked immunosorbent assay nor a rapid lateral flow immunoassay is commercially available for testing RRV. A multidisciplinary team of scientists united by the USDA SCRI project entitled Combating rose rosette disease: Short and long term approaches is developing molecular and serological diagnostic tools for rapid and sensitive detection of RRV. This short review describes some of the molecular diagnostic tools currently developed, which include end-point RT-PCR and TaqMan RT-qPCR.

\section{AVAILABLE DIAGNOSTIC TOOLS}

The availability of the sequence information of four genomic RNA segments-RNA1 (RdRp), RNA2 (glycoprotein), RNA3 (nucleocapsid), and RNA4 (movement protein)facilitated the development of the first molecular diagnostic method based on end-point RTPCR. This method used specific primers designed based on the RNA1 genomic segment of RRV (Laney et al., 2011). The primer sequences were RRV F 5'-CAGAATGAACCATAGATGTC-3' and RRV R 5'ATGGTCTGCTCGAGATT-3' . This method requires the following cycling conditions: reverse transcription at $48^{\circ} \mathrm{C}$ for $30 \mathrm{~min}$; initial denaturation at $94{ }^{\circ} \mathrm{C}$ for $2 \mathrm{~min}$; followed by 30 cycles of $94^{\circ} \mathrm{C}$ for $30 \mathrm{~s}$, annealing at $53^{\circ} \mathrm{C}$ for $10 \mathrm{~s}$, and extension at $72{ }^{\circ} \mathrm{C}$ for $30 \mathrm{~s}$; and a final extension for $10 \mathrm{~min}$ at $72{ }^{\circ} \mathrm{C}$. This initial primer set was used for testing symptomatic rose tissues of 84 cultivated and Rosa multiflora roses collected from nine states, along with 30 asymptomatic plants (20 from Arkansas and five each from Missouri and Tennessee). RRV was detected in all symptomatic roses but not in the asymptomatic plants. These primers are still in use in 
a number of plant diagnostic clinics for routine testing of RRV. The same primer set was later found to be less sensitive and often inconsistent in the detection of the virus from symptomatic tissues (Babu et al., 2016b; J. Olson, personal communication).

\section{DEVELOPMENT OF REAL-TIME RT-PCR DIAGNOSTIC TOOLS}

Nucleic acid-based methods including end-point polymerase chain reaction (PCR) and RT-PCR are widely used in virus detection (Mackay et al., 2002); however, the sensitivity of these techniques may be questionable in cases when low virus titer is combined with the presence of inhibitors, which is the case for rose tissue infected by RRV. The development of quantitative realtime PCR has revolutionized plant virus detection (Balaji et al., 2003; Boonham et al., 2002; Drosten et al., 2002; Eun et al., 2000; Jarosova and Kundu, 2010; Korimbocus et al., 2002; Lunello et al., 2004; Mortimer-Jones et al., 2009; Mumford et al., 2000; Roberts et al., 2000; Schoen et al., 1996) because of its increased sensitivity (100-1000-fold more sensitive than end-point PCR/RT-PCR), accuracy, and high throughput capability (Mackay et al., 2002). Seeking for more consistent assays, we hypothesized that it was possible to develop a RT-qPCR assay adjustable to different reagent formats targeting different genomic regions of the virus with increased specificity and sensitivity.

The RRV multidisciplinary team developed a diagnostic tool for the detection of RRV that consists of a single pair of diagnostic primers, which can be used with three different RT-PCR chemistries: endpoint RT-PCR, TaqMan RT-qPCR, and SYBR green-based RT-qPCR which can be coupled with high-resolution melting analysis (Dobhal et al., 2016). The implementation of an assay consisting of a single primer set to serve three different chemistries brings flexibility to diagnosticians furnished with different equipment capabilities in a diagnostic network. Further improvement contributed after publication of Dobhal et al. (2016) includes the substitution of SYBR green by
LCGreen using same reported stepwise denaturation increments conditions for improved accuracy. The primers were designed after the analysis of the nucleocapsid gene RNA3 of the RRV. The sequences of primers, probe, and their characteristics are listed in Table 1. Moreover, a synthetic, clonable, and noninfectious multitarget artificial positive control (APC) (plasmid) containing forward and reverse complement sequences of the designed primers and probe for RRV, along with the primer sequences of five other viruses of interest in ornamental crops including Cucumber mosaic virus, Hosta virus X, Tobacco mosaic virus, Tomato spotted wilt orthotospovirus, and Impatiens necrotic spot orthotospovirus, was engineered for routine application in detection and diagnostic assays. The construct was designed to be used as a source of positive control for the testing of RRV (amplifies a 125 bp product) and other five viruses (Fig. 1). The cycling conditions for the primers and probe are as follows:

a) Two-step end-point RT-PCR: Reverse transcription at $48{ }^{\circ} \mathrm{C}$ for $30 \mathrm{~min}$; cDNA amplification $94{ }^{\circ} \mathrm{C}$ for $3 \mathrm{~min}$; followed by 38 cycles of $94{ }^{\circ} \mathrm{C}$ for $20 \mathrm{~s}$, $56{ }^{\circ} \mathrm{C}$ for $30 \mathrm{~s}$, and $72{ }^{\circ} \mathrm{C}$ for $30 \mathrm{~s}$; and final extension at $72{ }^{\circ} \mathrm{C}$ for $3 \mathrm{~min}$.

b) TaqMan RT-qPCR assay: Reverse transcription at $48{ }^{\circ} \mathrm{C}$ for $30 \mathrm{~min}$; followed by two initial holds at 50 and $95{ }^{\circ} \mathrm{C}, 2 \mathrm{~min}$ each; followed by 40 cycles: $95^{\circ} \mathrm{C}$ for $20 \mathrm{~s}$ and $58^{\circ} \mathrm{C}$ for $45 \mathrm{~s}$.

c) SYBR green assay coupled with highresolution melting (HRM) analysis: Reverse transcription $48^{\circ} \mathrm{C}$ for $30 \mathrm{~min}$; cDNA amplification at $50^{\circ} \mathrm{C}$ and $95^{\circ} \mathrm{C}$ $2 \mathrm{~min}$ each, followed by 40 cycles at $95^{\circ} \mathrm{C}$ for $20 \mathrm{~s}$ and $54{ }^{\circ} \mathrm{C}$ for $45 \mathrm{~s}$.

After amplification, high-resolution melting analysis was performed as previously described using a stepwise denaturation from 65 to $99{ }^{\circ} \mathrm{C}$ with $0.2{ }^{\circ} \mathrm{C}$ increments at each step, a default of $90 \mathrm{~s}$ of pre-melt conditioning on the first step and a $2 \mathrm{~s}$ stop for each step afterward (Dobhal et al., 2016). Specificity analysis of the primers and probe with other near-neighbor viruses and viruses commonly infecting roses including Apple mosaic virus,
Arabis mosaic virus, Groundnut ringspot orthotospovirus, High plains wheat mosaic virus (formerly High plains virus), Impatiens necrotic spot orthotospovirus, Maize stripe tenuivirus, Prunus necrotic ringspot virus, Tobacco mosaic virus, Tomato chlorotic spot virus, Tomato spotted wilt orthotospovirus, and Tomato ringspot virus did not amplify any product, indicating the specificity of the primers and probe to RRV. Further sensitivity analysis of the diluted APC plasmids from $1 \mathrm{ng}$ to $1 \mathrm{fg}$ demonstrated that the primers are highly sensitive to a detection limit of $1 \mathrm{fg} / \mu \mathrm{L}$, for all the three RT-PCR chemistries. Total RNA extracted using RNeasy Plant Mini kit from 30 symptomatic and asymptomatic rose samples from eight different states in the United States were tested with end-point RT-PCR and TaqMan RT-qPCR. The assays tested positive with all collected samples and were able to detect RRV in asymptomatic plant samples 3 months before the onset of visual symptoms. The plants were field-monitored samples from Edmond, OK. These particular plants were initially healthy looking and tested RRV positive until dying. We speculate that the rose plants get hardly damaged because of both RRV and winter.

Even though RRV is reported to have little genetic variability within the four reported genomic RNA segments RNA1, RNA2, RNA3, and RNA4 (Laney et al,, 2011), additional studies with isolates from different geographic locations need to be conducted. In general, RNA viruses are considered to have a high mutational rate (Jenkins et al., 2002), and hence, they may acquire synonymous or silent nucleotide mutations within primer and probe target sequences, allowing them to potentially evade detection and resulting in false negatives. To overcome these issues, TaqMan RT-qPCR assays based on multiple gene targets were developed for the detection of RRV (Babu et al., 2016b). The use of multiple gene targets offers additional confirmatory testing for operators in diagnostic networks. The sequence of the primers and probes and their characteristics is listed in Table 1. The TaqMan RT-qPCR was performed with the following thermal program:

Table 1. Details of primers and probes used for the detection of rose rosette emaravirus (RRV) for use in end-point reverse transcription-polymerase chain reaction (RT-PCR) and quantitative RT-PCR assays.

\begin{tabular}{|c|c|c|c|c|c|c|c|c|}
\hline $\begin{array}{l}\text { Genomic RNA } \\
\text { segment }\end{array}$ & $\begin{array}{c}\text { Primers and } \\
\text { probes }\end{array}$ & Sequence $\left(5^{\prime}-3^{\prime}\right)$ & bp & Temp $\left({ }^{\circ} \mathrm{C}\right)$ & GC $(\%)$ & $\begin{array}{l}\text { Target } \\
\text { region }\end{array}$ & $\begin{array}{l}\text { Amplicon } \\
\text { size (bp) }\end{array}$ & Reference \\
\hline \multirow{2}{*}{ RNA 3} & RRV2R & ССТАTAGCTTCATCATTССТСТTTG & 25 & 59.6 & 40 & $559-663$ & 104 & \\
\hline & RRVP & TGCTAGAGACATTGGTACAACAAGCAA & 27 & 65.1 & 40.7 & & & \\
\hline & RRV_2-1Probe & ACAGCTGAAGCCATCATGAACCTT & 24 & 67 & 46 & & & \\
\hline & RRV_2-1Rev & TGGAGCCGTTGAATGCTTAG & 20 & 62 & 50 & & & \\
\hline RNA2 & RRV_2-2For & CCATTGCAGGTTGTTGCATT & 20 & 62 & 45 & $145-245$ & 100 & \\
\hline \multirow[t]{3}{*}{ RNA3 } & RRV_3-2For & ACACTCTTGCAGCTGATACTG & 21 & 62 & 47.6 & $65-182$ & 117 & \\
\hline & RRV_3-2Probe & AGCTTCGGGTCCTCAAGTTGACAA & 24 & 68 & 50 & & & \\
\hline & RRV_3-2Rev & CTGGGTCCAATTCTGAACTCTC & 22 & 62 & 50 & & & \\
\hline \multirow[t]{3}{*}{ RNA3 } & RRV_3-5For & CTGATACTGTTATCATCGGAGCTG & 24 & 62 & 45.8 & $77-171$ & 94 & \\
\hline & RRV_3-5Probe & AGCTTCGGGTCCTCAAGTTGACAA & 24 & 68 & 50 & & & \\
\hline & RRV_3-5Rev & TCTGAACTCTCAGGCTTCACTA & 22 & 62 & 45.5 & & & \\
\hline
\end{tabular}




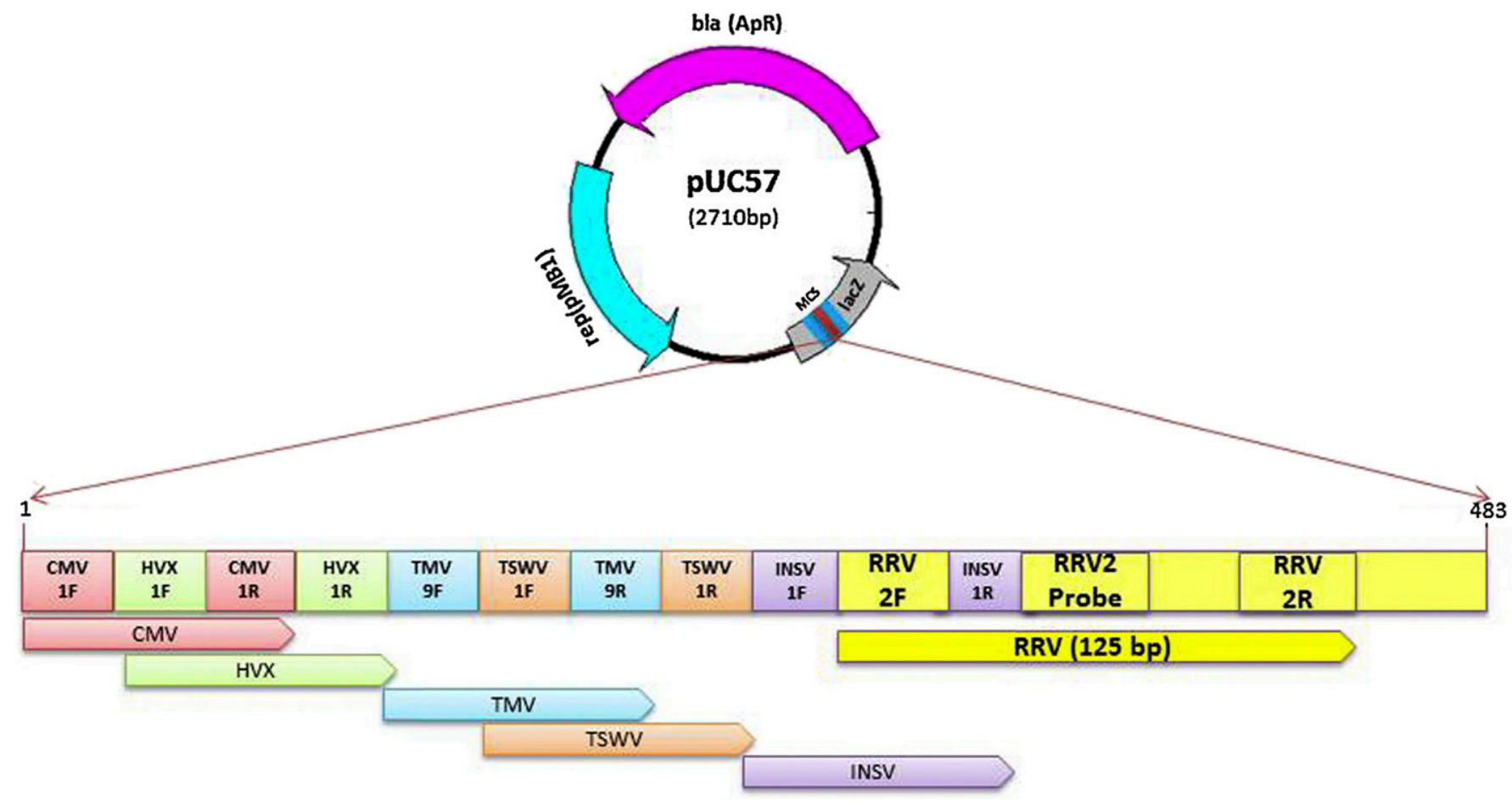

Fig. 1. The artificial positive control, synthetically constructed to be made by a tandem of forward and reverse complement primer sequences to include probes from rose rosette emaravirus (yellow) and other five viruses, ligated into a multiple cloning site of pUC57. Note that a probe sequence is included to allow quantitative polymerase chain reaction (PCR). Each PCR product has a unique sequence for each target virus which is useful for PCR product verification and quality control. (reprinted with permission; Dobhal et al., 2016).

$50{ }^{\circ} \mathrm{C}$ for $15 \mathrm{~min}, 95^{\circ} \mathrm{C}$ for $2 \mathrm{~min}$, followed by 40 cycles at $95^{\circ} \mathrm{C}$ for $15 \mathrm{~s}, 55^{\circ} \mathrm{C}$ for $15 \mathrm{~s}$, and $72{ }^{\circ} \mathrm{C}$ for $30 \mathrm{~s}$. The primer sets for the three additional RRV gene targets were highly specific, when tested against other viruses that frequently coinfect rose plants (Alfalfa mosaic virus, Apple mosaic virus, Arabis mosaic virus, Cucumber mosaic virus 1, Cucumber mosaic virus 2, Impatiens necrotic spot orthotospovirus, Prunus necrotic ringspot virus, Tobacco mosaic virus, Tobacco ringspot virus, Tobacco streak virus, Tomato ringspot virus, and Tomato spotted wilt orthotospovirus) including two taxonomically (genus) related viruses (Maize red stripe tenuivirus or Wheat mosaic virus). Sensitivity analysis of these primers using viral RNA transcripts indicated that all four primer/probe sets were able to detect the virus up to $1 \mathrm{fg} / \mu \mathrm{L}$. All primers and probes were assessed three times over a period of 1 month using infected RRV samples (confirmed by RT-PCR) confirming their high reproducibility as compared with the inconsistencies reported with previously existing assays. All four primer/probe sets were tested against the total RNA of 15 RRV-infected Double Knock Out roses and one asymptomatic plant, collected during 2013-15 (stored in -80 ${ }^{\circ} \mathrm{C}$ ) from different states in the United States, and tested positive for 13 symptomatic plant samples (87\%). The asymptomatic plant tested negative for RRV. Failure of the primer/probe sets in detecting the RRV from two samples has been attributed to the degraded RNA or inhibitors in samples stored in $-80{ }^{\circ} \mathrm{C}$ for long term.

For molecular diagnostics of RRV, the best source of samples was fresh young leaves. Even though samples stored in $-80{ }^{\circ} \mathrm{C}$ may test positive for RRV, it is always good to rely on fresh tissue sources. A comparative analysis of the various diagnostic tools available for RRV is presented in Table 2 . The reviewed molecular diagnostic tools can be efficiently implemented by diagnostic laboratories for rapid detection and identification of RRV to support commercial nurseries, landscapers, and home owners in early stages of virus identification, facilitating and speeding the implementation of timely eradication measures, which will minimize the risk associated with the spread of the RRV to healthy roses. Diagnostic research regarding RRV and Emaravirus is not completed. The RRV multidisciplinary team actively focuses on developing a genus broad detection and diagnostic tool for Emaravirus and explores sensitive color visualization assays using selfquenched primers (SqPs) and sample processing methods to circumvent the presence of putative PCR inhibitors in rose tissues.

\section{FORTHCOMING RRV DIAGNOSTICS}

Thermophilic helicase-dependent amplification (tHDA) is an isothermal nucleic acid amplification technique that does not require a temperature cycling. A comparison of primers designed with the same thermodynamic criteria but different GC content in their targeted amplification products is in progress to assess fluorescence using $\mathrm{SqPs}$ reacting in tHDA standard temperature and chemistry. Model viruses tested are RRV, High plains wheat mosaic emaravirus, and Hosta virus $X$. The products amplified by quantitative thermophilic helicase dependent amplification (qtHDA) with SqPs are visualized in $2 \%$ agarose gel electrophoresis. Detection limits using plasmid DNA carrying the target sequences for RRV and High plains wheat mosaic virus are $0.0001 \mathrm{ng}$. This study explored primer design criteria for tHDA with $\mathrm{SqP}$ assays exploring alternative sensitive detection. The use of SqPs may reduce the cost of qPCR and qtHDA by half and still maintain good sensitivity. tHDA with $\mathrm{SqP}$ also bring new possibilities for field deployment primer design in biosecurity and microbial forensics (Molina Cárdenas et al., 2016).

Loop-mediated amplification of DNA (LAMP) is another isothermal amplification method that combines specificity, sensitivity, and easy points of care implementation because it allows visual detection. Alignments of RRV P3 (RNA3) and P4 (RNA 4) gene sequences allowed LAMP primer design for broad detection of reported isolates. Optimal isothermal amplification was obtained with Bst 2.0 WarmStart DNA polymerase and Optigene master mix. The detections were $1 \mathrm{pg} / \mu \mathrm{L}$ and $1 \mathrm{fg} / \mu \mathrm{L}$, respectively, using plasmid carrying the targeted sequence. Products were also visualized by electrophoresis. The visual detection limit of plasmid in colorimetric reactions using hydroxynaphthol blue $(120 \mu \mathrm{M})$ without bovine serum albumin (BSA) and polyvinylpyrrolidone (PVP) was $0.01 \mathrm{ng} / \mu \mathrm{L}$. No crossreactions with cDNA from 10 frequently rose coinfecting or related viruses were detected. The method has potential application in biosecurity, microbial forensics, and nursery virus-free monitoring of germplasm (Salazar Aguirre et al., 2016). 
Table 2. Comparative features of the currently available molecular diagnostic tools for rose rosette emaravirus (RRV).

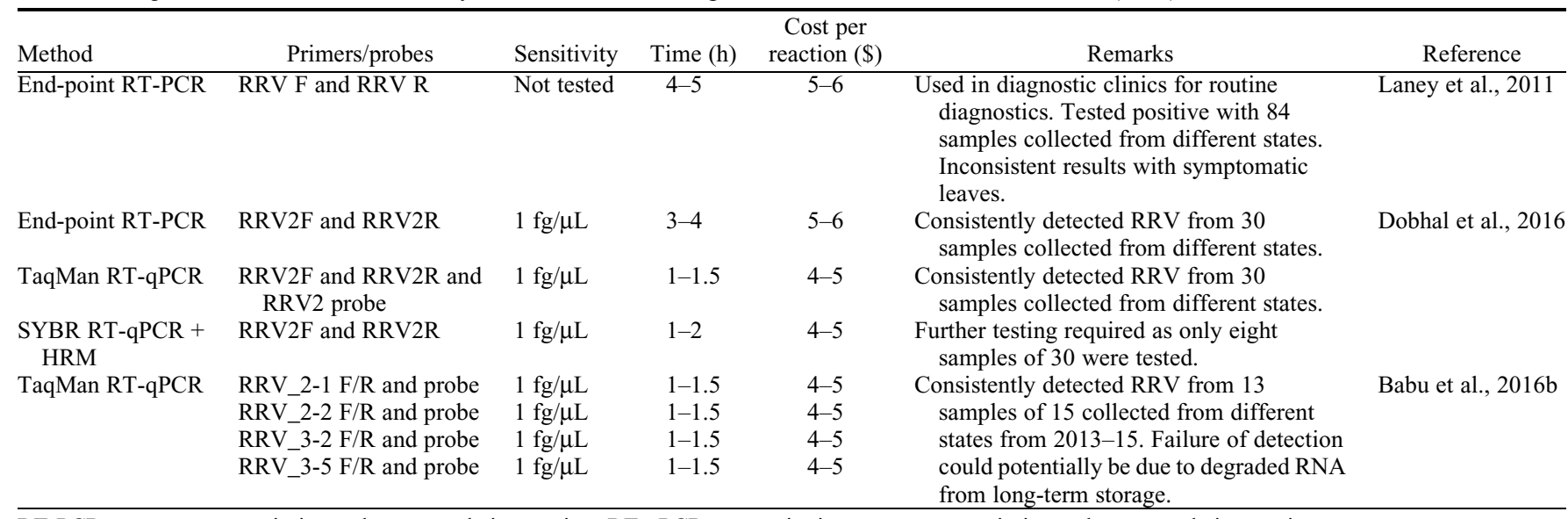

RT-PCR = reverse transcription-polymerase chain reaction; RT-qPCR = quantitative reverse transcription-polymerase chain reaction.

The genus Emaravirus has six confirmed species and two unclassified species, attributed to variety of symptoms. Seeking rapid detection and an effective screening of existing and new emaraviruses for detection/diagnostics, taxonomic confirmation, plant virus discovery and biosecurity applications, sequences of RdRp (RNA 1) of European mountain ash ringspot-associated emaravirus, Fig mosaic emaravirus, High plains wheat mosaic emaravirus, Pigeonpea sterility mosaic emaravirus, Pigeonpea sterility mosaic emaravirus 2, Raspberry leaf blotch emaravirus, Redbud yellow ringspot-associated emaravirus, and RRV were studied and genus broad-specific detection primers designed. The sensitivity of this RT-PCR was found to be $100 \mathrm{fg} /$ reaction. The multiple Emaravirus detection was confirmed with rose samples showing symptoms caused by European mountain ash ringspot-associated emaravirus, Fig mosaic emaravirus, High plains wheat mosaic emaravirus, and RRV. Other emaraviruses, Pigeonpea sterility mosaic emaravirus, Pigeonpea sterility mosaic emaravirus 2, Raspberry leaf blotch emaravirus, and Redbud yellow ringspot-associated emaravirus, were detected in silico using Primer-Blast. This method will address the need for sensitive molecular detection and discovery of novel emaraviruses.

This review described current and forthcoming different diagnostic tools developed for RRV, which have been developed seeking extended reliability, high sensitivity, and easy implementation for detection and identification in laboratories providing diagnostic services and confirmation of RRV-infected samples (Olmedo-Velarde et al., 2016).

\section{Literature Cited}

Amrine, J. 2002. Multiflora rose, p. 265-292. In: R.V. Driesche, B. Blossey, M. Hoddle, S. Lyon, and R. Reardon (eds.). Biological control of invasive plants in the Eastern United States. USDA For. Serv.

Amrine, J.W., D.F. Hindal, T.A. Stasny, R.L. Williams, and C.C. Coffman. 1988. Transmission of the rose rosette disease agent to Rosa multiflora by Phyllocoptes fructiphylus
(Acari: Eriophyidae). Entomol. News 99:239_ 252.

Babu, B., A. Jeyaprakash, D. Jones, T.S. Schubert, C. Baker, B.K. Washburn, S. Miller, K. Poduch, G.W. Knox, F.M. Ochoa-Corona, and M.L. Paret. 2016b. Development of a rapid, sensitive TaqMan real-time RT-PCR assay for the detection of Rose rosette virus using multiple gene targets. J. Virol. Methods 235:41-50.

Babu, B., B.K. Washburn, K. Poduch, G.W. Knox, and M.L. Paret. 2016a. Identification and characterization of two novel genomic RNA segments RNA5 and RNA6 in Rose rosette virus infecting roses. Acta Virol. 60:156-165.

Balaji, B., D.B. Bucholtz, and J.M. Anderson. 2003. Barley yellow dwarf virus and Cereal yellow dwarf virus quantitation by real-time polymerase chain reaction in resistant and susceptible plants. Phytopathology 93:13861392.

Boonham, N., P. Smith, K. Walsh, J. Tame, J. Morris, N. Spence, J. Benison, and I. Barker. 2002. The detection of Tomato spotted wilt virus (TSWV) in individual thrips vectors using real time fluorescent RT-PCR (TaqMan). J. Virol. Methods 101:37-48.

Di Bello, P.L., T. Ho, and I.E. Tzanetakis. 2015. The evolution of emaraviruses is becoming more complex: Seven segments identified in the causal agent of rose rosette disease. Virus Res. 210:241-244.

Dobhal, S., J.D. Olson, M. Arif, J.A. Garcia Suarez, and F.M. Ochoa-Corona. 2016. A simplified strategy for sensitive detection of Rose rosette virus compatible with three RT-PCR chemistries. J. Virol. Methods 232:47-56.

Drosten, C., S. Gottig, S. Schilling, M. Asper, M. Panning, H. Schmitz, and S. Gunther. 2002. Rapid detection and quantitation of RNA of Ebola and Marburg viruses, Lassa virus, Crimean-Congo hemorrhagic fever virus, Rift valley fever virus, Dengue virus, and Yellow fever virus by real-time reverse transcriptionPCR. J. Clin. Microbiol. 40:2323-2330.

Epstein, A.H. and J.H. Hill. 1999. Status of rose rosette disease as a biological control for multiflora rose. Plant Dis. 83:92-101.

Eun, A., M. Seoh, and S. Wong. 2000. Simultaneous quantitation of two orchid viruses by TaqMan real-time RT-PCR. J. Virol. Methods $87: 151-160$

Gergerich, R.C. and K.S. Kim. 1983. A description of the causal agent of rose rosette disease Arkansas Farm Res. 32:7.
Gergerich, R.C., K.S. Kim, and E.W. Kitajima. 1983. A particle of unique morphology associated with the disease of rose in northwest Arkansas. Phytopathology 73:500-501.

Jarosova, J. and J.K. Kundu. 2010. Detection of Prune dwarf virus by one-step RT-PCR and its quantitation by real-time PCR. J. Virol. Methods 164:139-144.

Jenkins, G.M., A. Rambaut, O.G. Pybus, and E.C. Holmes. 2002. Rates of molecular evolution in RNA viruses: A quantitative phylogenetic analysis. J. Mol. Evol. 54:156165.

Korimbocus, J., C. Danks, N. Boonham, I. Barker, and D. Coates. 2002. Improved detection of Sugarcane leaf virus using a real-time fluorescent reverse-transcription polymerase chain reaction assay. Phytopathology 90:448-453.

Laney, A.G., K.E. Keller, R.R. Martin, and I.E. Tzanetakis. 2011. A discovery 70 years in the making: Characterization of the Rose rosette virus. J. Gen. Virol. 92:1727-1732.

Lunello, P., C. Mansilla, V. Conci, and F. Ponz. 2004. Ultra-sensitive detection of two garlic Potyviruses using a real-time fluorescent $\left(\right.$ Taqman $\left.^{\circledR}\right)$ RT-PCR assay. J. Virol. Methods 118:15-21.

Mackay, I., K. Arden, and A. Nitsche. 2002. Realtime PCR in virology. Nucleic Acids Res. 30:1292-1305.

Molina Cárdenas, S., A. Salazar Aguirre, F. OchoaCorona, and J. Olson. 2016. Fluorogenic detection of plant viruses by helicase dependent amplification with self-quenched primers . Phytopathology 106:S4.9 (abstr.).

Mortimer-Jones, S.M., M.G.K. Jones, R.A.C. Jones, G. Thomson, and G.I. Dwyer. 2009. A single tube, quantitative real-time RTPCR assay that detects four potato viruses simultaneously. J. Virol. Methods 161:289296.

Mumford, R., I. Barker, K. Walsh, and N. Boonham. 2000. Detection of Potato mop-top virus and Tobacco rattle virus using a real-time fluorescent (TaqMan) RT-PCR assay. J. Virol. Methods 103:109-120.

Olmedo-Velarde, A., F. Ochoa-Corona, and $\mathrm{T}$. Elbeaino. 2016. Toward broad detection of emaraviruses: Endpoint RT-PCR. Phytopathology 106:S4.118 (abstr.).

Roberts, C., R. Dietzgen, L. Heelan, and D. Maclean. 2000. Real-time RT-PCR fluorescent detection of Tomato spotted wilt virus. J. Virol. Methods 88:1-8. 
Salazar Aguirre, A., S. Molina Cárdenas, F. Ochoa-Corona, and J. Olson. 2016. Rose rosette virus detection using loop-mediated isothermal amplification (LAMP). Phytopathology 106:S4.117 (abstr.).

Schoen, C., D. Knoor, and G. Leone. 1996. Detection of Potato leafroll virus in dormant potato tubers by immunocapture and fluorogenic $5^{\prime}$ nuclease RT-PCR assay. Phytopathology 86:993-999.
Stanley, T. 2013. Rose disease killing hundreds of bushes at Tulsa Rose Garden. 15 Jan. 2017 $<$ http://www.tulsaworld.com/homepagelatest/ rose-disease-killing-hundreds-of-bushes- at tulsarose-garden/article_ad10e378-31f7-11e3-9e39001a4bcf6878.html>

U.S. Department of Agriculture. 2015. 2012 census of agriculture: Census of horticultural specialties (2014), Vol. 3. Washington, D.C.
Windham, M., A. Windham, and F. Hale. 2014a. Observations on rose rosette disease. 15 Jan. 2017. <http://www.newenglandgrows.org/pdfs/ ho_WindhamRoseRosette.pdf>.

Windham, M., A. Windham, F. Hale, and W. Hitch. 2014b. Rose rosette: Identification and management. SNA Res. Conf. Vol. 59. p. 143-146. 15 Jan. 2017. <http://www.sna.org/Resources/ Documents/14resprosec06.pdf>. 